\title{
SOCIO ECONOMIC STATUS AND EXPECTATION ON CORPORATE SOCIAL RESPONSIBILITY - RELATIONSHIP STUDY
}

\author{
M. Selvakumar ${ }^{1}$, B. Arumugam ${ }^{2}$, V. Sathyalakshmi ${ }^{3}$ and R. Mohammed Abubakkar Siddique ${ }^{3}$ \\ ${ }^{1,3,4}$ Department of Commerce, Ayya Nadar Janaki Ammal College, India \\ ${ }^{2}$ Department of Commerce, Annai Fatima College, India
}

\begin{abstract}
The purpose of this paper is to analyze the relationship between socio economic status and customer expectation on corporate social responsibility of banks in Virudhunagar District. The researcher has applied Chi-square test to study the relationship between the socioeconomic variables and their level of expectation of Corporate Social Responsibilities of banks. The Chi-square test reveals that there is no relationship between literacy level, period of transaction and category of bank and their level of expectations towards the CSR activities of banks. This study also reveals that there is a relationship between gender, age, place of residence, educational status, occupation, monthly income and type of account and their level of expectations towards the CSR activities of banks.
\end{abstract}

\section{Keywords:}

CSR, Banks, Chi-Square Test, Corporate Social Responsibility

\section{INTRODUCTION}

The concept of Corporate Social Responsibility (CSR) is not a new one but its focal point changes with the changing requirements of business and varying social needs. The concept of CSR was first mentioned in 1953 in the publication of "Social responsibilities of businessman" by William J.Bowen. However, the term CSR became only popular in the 1990s, when the German Beta Pharma Generic Pharmaceutical Company decided to implement CSR.

CSR is a concept whereby companies decide voluntarily to contribute to a better society and a cleaner environment. It is represented by the contributions undertaken by companies to society through its business activities and its social investment. CSR has been making an increasingly prominent impact in the Indian social system by supplementing development projects. But it is not a novel concept in India as its historical roots goes till the Vedic age.

Today Banking Sector growing larger and powerful than before. Various Non-government organizations put pressure on Banks to act responsibly towards their stakeholders. Thus, pressure has given rise to the concept named Corporate Social Responsibility [1].

CSR also called corporate conscience, corporate citizenship, sustainable responsible business or others, is a concept that has become a standard part of most business models in the last decade. It is commonly defined as being the integration of issues of concern held by the wider society in companies' business models or operations, and their interactions with stakeholders, on a voluntary basis i.e. going beyond what is legislated or regulated for [2].
The importance of corporate social responsibility has become an important issue for banks to address, ahead of corporate scandals in the beginning of this century which have had resulted in a slide in the level of trust that they used to enjoy [3]. Nowadays, many nationalized banks in India have created their individual brand image in the field of Corporate Social Responsibility (CSR) by taking various social initiatives in the era of social welfare and community development. The inventory contributions made by nationalized banks for economic growth in India have created their separate bodies towards financial growth [4].

Banks are also engrossed with various commitments towards fulfillment of Corporate Social Responsibility (CSR) to manage its diverse roles in society, as producer, employer, customer and citizen in a responsible manner. How a Bank meets its corporate responsibility goals is influenced by its history, vision of the founder, culture, experience, philosophy and its laws and regulations. However, Banks are under enormous pressure from its stakeholders, investors and media along with its customers to carry out business in a socially responsible and ethical way [5].

However, the challenge for the banking institutions is to determine a strong and innovative Corporate Social Responsibility strategy, which should deliver elevated performance in ethical, environmental and social areas. The banking institutions under this CSR concepts have recognized their responsibility towards the society and are making their contribution in the field of employment generation, education, health care, women welfare and women empowerment [6]. This article analyze the expectation of customers about CSR of banks according to the socio economic status.

\section{LITERATURE REVIEW}

To understand the concept of CSR and to know the existing research in CSR, the researcher made the detailed review in the field of CSR. That makes the research to know about the view on CSR clear. The following paragraphs about CSR, which are drawn for the existing literatures, are very useful to build the research methods for this study.

In India, the banking sector is showing interest in integrating sustainability into their business models but its CSR reporting practices are far from satisfaction. There are only a few banks which report their activities on triple bottom line principles [7].

Basically, CSR is the contribution of organizations towards the betterment of the Society. CSR is an important part for all the organizations to practice with their work. CSR is the initiative of corporate so as to assess and take the responsibilities for the company's effect on environment and also the impact on the welfare of society [8]. A recent attention by consumers, workers, 
and government towards the concept of CSR was based on the idea that businesses exist not just for profit maximization. It is also recognized as a fundamental part of corporate marketing strategies in corporate identity article [9] Moreover, CSR has a great importance in today's business environment for socioeconomic developments and to contribute to the value of stakeholders' [10].

The Indian banks are making efforts in the CSR areas but still there is a requirement of more emphasis on CSR. There are some banks which are not even meeting the regulatory requirements. The public sector banks have overall highest contribution in CSR activities. Private sector banks and foreign banks are still lagging in this area [11]. Most banks use CSR as a marketing tool to spread the word about their business [12].

Banks are engaged in CSR activities mostly in the area of rural development, education, community welfare, women and children. There is a need for better CSR activities by the banks, which is possible by adding more and more social development issues link with corporate sector [13]. Customers have a positive approach towards corporate social responsibility. Very few customers are agreeing that CSR is a strategic tool for earning profit. Most of customers have given believe that CSR is a social responsibility tool and very helpful to solve the issues of society [14].

Corporate Social Responsibility (CSR) positively influences customer satisfaction toward banking service quality [15]. Financial performance is a key motivator for banks to CSR [16][17]. Impact of CSR on overall banking performance is significantly positive but individually it's different [18]. It is a tool to gain competitive advantage, has positive impact on employees' behavior, customers' behavior and in establishing a bank's image [19]. So, Implementation of CSR activity could help an organization to maintain its status in the eyes of its customers [20]. In addition, the demands for heightened levels of CSR in banks are being pressed worldwide due to increasing severe competitiveness and potential benefits given by CSR [21].

The financial institutions which implements CSR in their operations to earn more profit for the long term periods [22]. Through CSR initiatives, the banks spread the awareness of education between the people and helping them by giving scholarship and providing the atmosphere of education for the people who are living in the villages [23]

Corporate Social Responsibility (CSR) in banks has become a worldwide demand. Now a day, by recognizing CSR, banks from all over the world endorse programs of educational, cultural, and environmental, as well as health initiatives. Besides, there is a strong need for more research on CSR of banks. That ways, the researchers have chosen this study.

\section{OBJECTIVES OF THE STUDY}

The following are the objectives of the study.

- To analyze the socio economic status of the respondents.

- To examine the expectation of customers towards CSR of banks.
- To analyze the relationship between socio economic status and customer expectation on corporate social responsibility of banks.

- To offer suitable suggestions on the basis of findings of the study.

\section{RESEARCH METHODOLOGY}

This study is mainly planned to analyze the relationship between socio economic status and customer expectation towards corporate social responsibility of banks in Virudhunagar District. It is based on both primary and secondary data. The banking customers are large in number and it is not feasible to collect the data from all the banking customers from the study area. Therefore, it is decided to apply the sampling technique to study the current problem. The www.surveysystem.com is used to identify the sample size.

According to this website, 386 is identified as appropriate sample size. For the purpose this study, the population is divided into eight taluks such as Aruppukkottai, Kariapatti, Rajapalayam, Sattur, Sivakasi, Srivilliputur, Tiruchuli and Virudhunagar. Then the purposive sampling technique has been used to identify the sampling customers, proportionate to the population, from the taluks. The Table. 1 given below shows the taluk wise distribution of sample customers.

Table.1. Taluk Wise Distribution of Sample Customers

\begin{tabular}{|c|c|c|c|}
\hline S.No. & Taluks & $\begin{array}{c}\text { Population (Per cent to } \\
\text { Total) }\end{array}$ & $\begin{array}{l}\text { Sample } \\
\text { Size }\end{array}$ \\
\hline 1 & Aruppukattai & $2,48,186(12.77)$ & 49 \\
\hline 2 & Sivakasi & $4,27,072(21.98)$ & 85 \\
\hline 3 & Srivilliputtur & $2,92,895$ (15.07) & 58 \\
\hline 4 & Sattur & $1,68,659(8.68)$ & 34 \\
\hline 5 & Kariapatti & $1,05,329(5.42)$ & 21 \\
\hline 6 & Rajapalayam & $3,47,318(17.87)$ & 69 \\
\hline 7 & Tiruchuli & $1,03,068(5.30)$ & 20 \\
\hline 8 & Virudhunagar & $2,50,782(12.91)$ & 50 \\
\hline \multicolumn{3}{|r|}{ Total } & 386 \\
\hline
\end{tabular}

Source: Primary Data

The secondary data required for the study are collected from government reports, journals, books, bank records and websites. The collected data has been analyzed by using appropriate statistical tools like Percentage analysis, Reliability Test and Chisquare Test with the help of SPSS.

\section{RESULTS AND DISCUSSION}

\subsection{SOCIO ECONOMIC STATUS OF THE RESPONDENTS}

The Table. 1 shows that the socio-economic background of the customers in Virudhunagar district. It includes factors such as, gender, age, residential status, literacy level, educational qualification, occupation and monthly income and also shows a detailed report about the different account holder, period of transaction and category of bank. 
Table.2. Socio Economic Status of the Respondents

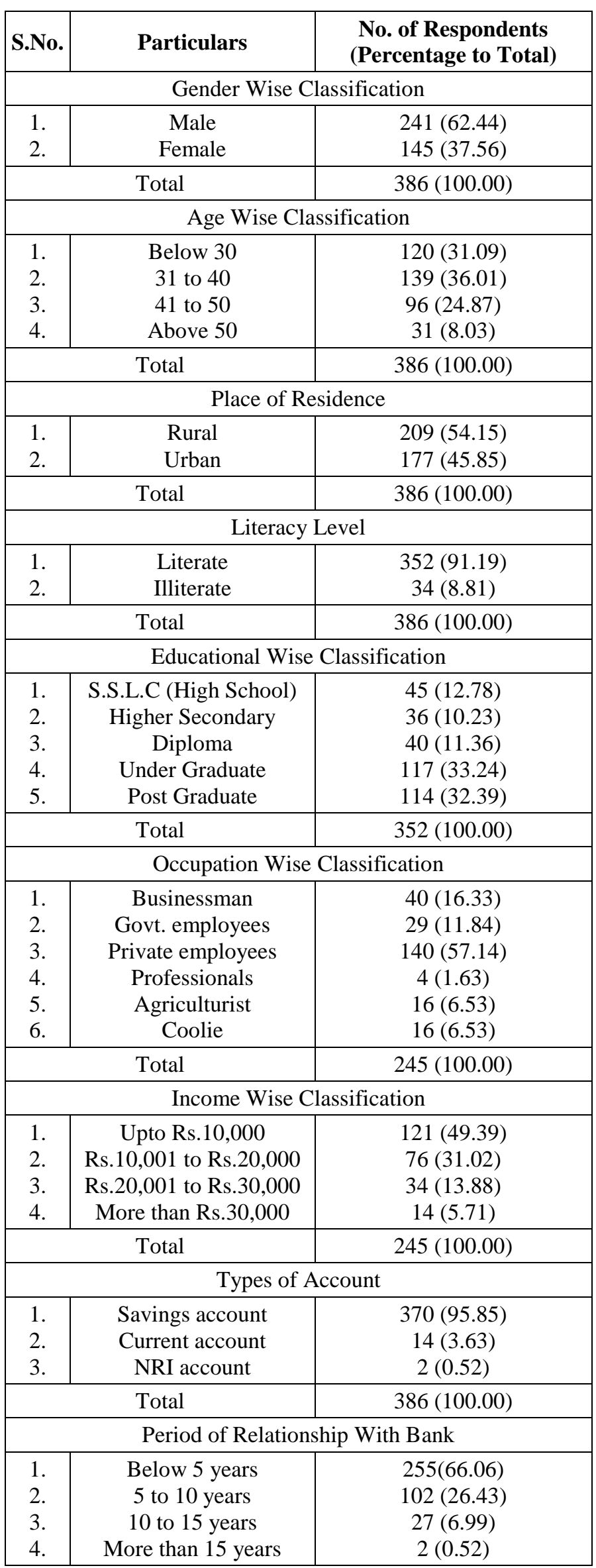

\begin{tabular}{|c|c|c|}
\hline & Total & $386(100.00)$ \\
\hline \multicolumn{3}{|c|}{ Bank Wise Classification } \\
\hline 1. & Public sector bank & $259(67.10)$ \\
\hline 2. & Private sector bank & $104(26.94)$ \\
\hline 3. & Regional rural bank & $13(3.36)$ \\
\hline 4. & Co-operative bank & $10(2.60)$ \\
\hline \multicolumn{2}{|r|}{ Total } & $386(100.00)$ \\
\hline
\end{tabular}

Source: Primary Data

The analysis of the surveyed data reveals that out of 386 customers, 241 customers $(62.44 \%)$ are male, 139 of them $(36.01 \%)$ are at the age group of 31 to 40 years, 209 respondents $(54.15 \%)$ are rural people, 352 respondents $(91.19 \%)$ are literate, 117 respondents $(33.24 \%)$ are under graduates, 140 customers $(57.14 \%)$ are private employees, 121 of them $(49.39 \%)$ have earn their monthly income up to Rs.10,000, 370 respondents (95.85\%) are maintained savings account in banks, 255 respondents $(66.06 \%)$ are having account with the bank for below 5 years and $259(67.10 \%)$ of the respondents are the customers of public sector bank.

\subsection{EXPECTATION OF CUSTOMERS TOWARDS THE CSR ACTIVITIES OF BANKS}

The researcher has also examined the expectation of customers towards the CSR activities of banks in Virudhunagar district. The view of customers on the services of the banks may vary from person to person. The level of expectation of the customers is meant to indicate the extent to which the CSR activities to be done by the banks. During the survey, the researcher has collected the data relating to opinion regarding the expectations of customers about the CSR activities of banks. The level of expectation is determined by the score values calculated for 43 statements which are related to the activities done by the banks by adopting scaling technique, namely liker's five point scale. The reliability of the scale is tested with the help of Cronbach's Alpha test by using SPSS. The Table. 3 shows the details of opinion of the respondents about their expectations towards Corporate Social Responsibility activities of banks in Virudhunagar District.

Table.3. Opinion about the Future Expectations of Customers about the CSR of Banks

\begin{tabular}{|c|c|c|c|c|c|}
\hline Statements & SA & $\mathbf{A}$ & $\mathbf{N}$ & DA & SDA \\
\hline $\begin{array}{c}\text { Give more types of loans } \\
\text { to all customers }\end{array}$ & $\begin{array}{c}139 \\
(36.01)\end{array}$ & $\begin{array}{c}216 \\
(55.96)\end{array}$ & $\begin{array}{c}16 \\
(4.15)\end{array}$ & $\begin{array}{c}9 \\
(2.33)\end{array}$ & $\begin{array}{c}6 \\
(1.55)\end{array}$ \\
\hline $\begin{array}{c}\text { Follow minimum } \\
\text { procedure for Account } \\
\text { opening }\end{array}$ & $\begin{array}{c}102 \\
(26.42)\end{array}$ & $\begin{array}{c}243 \\
(62.95)\end{array}$ & $\begin{array}{c}34 \\
(8.81)\end{array}$ & $\begin{array}{c}5 \\
(1.30)\end{array}$ & $\begin{array}{c}2 \\
(0.52)\end{array}$ \\
\hline $\begin{array}{c}\text { Charge minimum cost } \\
\text { for services }\end{array}$ & 118 & 199 & 52 & 13 & 4 \\
$(30.57)$ & $(51.55)$ & $(13.47)$ & $(3.37)$ & $(1.04)$ \\
\hline $\begin{array}{c}\text { Establish more ATM } \\
\text { centers in rural areas }\end{array}$ & $\begin{array}{c}114 \\
(29.53)\end{array}$ & $\begin{array}{c}208 \\
(53.89)\end{array}$ & $\begin{array}{c}40 \\
(10.36)\end{array}$ & $\begin{array}{c}20 \\
(5.18)\end{array}$ & $\begin{array}{c}4 \\
(1.04)\end{array}$ \\
\hline $\begin{array}{c}\text { Create awareness about } \\
\text { No Frill Accounts }\end{array}$ & $\begin{array}{c}119 \\
(30.83)\end{array}$ & $\begin{array}{c}168 \\
(43.52)\end{array}$ & $\begin{array}{c}70 \\
(18.14)\end{array}$ & $\begin{array}{c}18 \\
(4.66)\end{array}$ & $\begin{array}{c}11 \\
(2.85)\end{array}$ \\
\hline $\begin{array}{c}\text { Implement KYC Norms } \\
\text { effectively }\end{array}$ & $\begin{array}{c}110 \\
(28.50)\end{array}$ & $\begin{array}{c}170 \\
(44.04)\end{array}$ & $\begin{array}{c}70 \\
(18.14)\end{array}$ & $\begin{array}{c}28 \\
(7.25)\end{array}$ & $\begin{array}{c}8 \\
(2.07)\end{array}$ \\
\hline
\end{tabular}




\begin{tabular}{|c|c|c|c|c|c|}
\hline $\begin{array}{l}\text { Conduct awareness } \\
\text { programmes about } \\
\text { banking, E- Banking }\end{array}$ & $\begin{array}{l}119 \\
30.84)\end{array}$ & $\begin{array}{c}179 \\
(46.37)\end{array}$ & $\begin{array}{c}72 \\
(18.65)\end{array}$ & $\begin{array}{c}14 \\
(11.40)\end{array}$ & $\begin{array}{c}2 \\
(0.52\end{array}$ \\
\hline & & $\begin{array}{c}18 \\
46.8\end{array}$ & $\begin{array}{c}68 \\
17.62)\end{array}$ & $\begin{array}{c}20 \\
5.18)\end{array}$ & $\begin{array}{c}14 \\
(3.63\end{array}$ \\
\hline & $\begin{array}{c}125 \\
(32.38)\end{array}$ & $\begin{array}{c}172 \\
(44.56)\end{array}$ & $\begin{array}{c}57 \\
(14.77)\end{array}$ & $\begin{array}{l}26 \\
6.74)\end{array}$ & $\begin{array}{c}6 \\
(1.55\end{array}$ \\
\hline & $\begin{array}{c}139 \\
(36.01)\end{array}$ & $\begin{array}{c}155 \\
(40.16)\end{array}$ & $\begin{array}{c}51 \\
(13.21)\end{array}$ & $\begin{array}{c}24 \\
(6.22)\end{array}$ & $\begin{array}{c}17 \\
(4.40\end{array}$ \\
\hline & $(34.46)$ & $\begin{array}{c}181 \\
(46.89)\end{array}$ & $\begin{array}{c}53 \\
(13.73)\end{array}$ & $\begin{array}{c}15 \\
(3.89) \\
\end{array}$ & $\begin{array}{c}4 \\
(1.03\end{array}$ \\
\hline $\mathrm{cu}$ & $\begin{array}{c}134 \\
(34.72)\end{array}$ & $\begin{array}{c}172 \\
(44.56)\end{array}$ & $\begin{array}{c}51 \\
(13.21)\end{array}$ & $\begin{array}{c}12 \\
(3.11)\end{array}$ & $\begin{array}{c}17 \\
(4.40\end{array}$ \\
\hline & $\begin{array}{c}127 \\
(32.90) \\
\end{array}$ & $\begin{array}{c}188 \\
(48.71)\end{array}$ & $\begin{array}{c}57 \\
(14.77)\end{array}$ & $\begin{array}{c}10 \\
(2.59) \\
\end{array}$ & $\begin{array}{c}4 \\
(1.03 \\
\end{array}$ \\
\hline $\begin{array}{r}\text { Financi } \\
\mathrm{C}\end{array}$ & $\begin{array}{c}151 \\
(39.12)\end{array}$ & $\begin{array}{c}175 \\
(45.34)\end{array}$ & $\begin{array}{c}38 \\
(9.84)\end{array}$ & $\begin{array}{c}14 \\
(3.63)\end{array}$ & $\begin{array}{c}8 \\
(2.07\end{array}$ \\
\hline & $\begin{array}{c}132 \\
34.20) \\
\end{array}$ & $\begin{array}{c}167 \\
(43.26)\end{array}$ & $\begin{array}{c}65 \\
(16.85) \\
\end{array}$ & $\begin{array}{c}18 \\
(4.66)\end{array}$ & $\begin{array}{c}4 \\
(1.03 \\
\end{array}$ \\
\hline $\begin{array}{r}\text { Ado } \\
\text { Technolo } \\
\mathrm{n}\end{array}$ & $\begin{array}{c}132 \\
(34.20)\end{array}$ & $\begin{array}{c}168 \\
(43.52)\end{array}$ & $\begin{array}{c}68 \\
(17.62)\end{array}$ & $\begin{array}{c}12 \\
(3.11)\end{array}$ & $\begin{array}{c}6 \\
(1.55\end{array}$ \\
\hline & $\begin{array}{c}136 \\
(35.23)\end{array}$ & $\begin{array}{c}149 \\
(38.60)\end{array}$ & $\begin{array}{c}66 \\
(17.10)\end{array}$ & $\begin{array}{c}26 \\
(6.74)\end{array}$ & $\begin{array}{c}9 \\
(2.33\end{array}$ \\
\hline & & & (13.73) & $(4.15)$ & $\begin{array}{c}6 \\
(1.55 \\
\end{array}$ \\
\hline 1 & $\begin{array}{c}14 \\
(37.56)\end{array}$ & $\begin{array}{c}156 \\
(40.42)\end{array}$ & $\begin{array}{c}51 \\
(13.21) \\
\end{array}$ & $\begin{array}{c}23 \\
(5.96) \\
\end{array}$ & $\begin{array}{c}11 \\
(2.85\end{array}$ \\
\hline & & & $\begin{array}{c}66 \\
(17.10) \\
\end{array}$ & $\begin{array}{c}27 \\
(6.99) \\
\end{array}$ & $\begin{array}{c}3 \\
(0.78\end{array}$ \\
\hline & 142 & $\begin{array}{c}159 \\
(41.19)\end{array}$ & $\begin{array}{c}63 \\
(16.32)\end{array}$ & $\begin{array}{c}18 \\
(4.67)\end{array}$ & $\begin{array}{c}4 \\
(1.03\end{array}$ \\
\hline & 138 & $\begin{array}{c}161 \\
(41.71) \\
\end{array}$ & $\begin{array}{c}56 \\
(14.51) \\
\end{array}$ & \begin{tabular}{|c|}
19 \\
$(4.92)$ \\
\end{tabular} & $\begin{array}{c}12 \\
(3.11 \\
\end{array}$ \\
\hline $\begin{array}{r}\text { Enc } \\
p\end{array}$ & $\begin{array}{c}142 \\
(36.79)\end{array}$ & $\begin{array}{c}157 \\
(40.67)\end{array}$ & $\begin{array}{c}53 \\
(13.73)\end{array}$ & $\begin{array}{c}26 \\
(6.74)\end{array}$ & $\begin{array}{c}8 \\
(2.07\end{array}$ \\
\hline Follow Paper less work & (26.94) & $(45.34)$ & $\begin{array}{c}75 \\
(19.43)\end{array}$ & $\begin{array}{c}20 \\
(5.18) \\
\end{array}$ & $\begin{array}{c}12 \\
(3.11\end{array}$ \\
\hline $\begin{array}{r}\text { The Banl } \\
\text { to }\end{array}$ & $\begin{array}{c}83 \\
(21.50)\end{array}$ & \begin{tabular}{|c}
144 \\
$(37.3)$
\end{tabular} & $\begin{array}{c}89 \\
(23.06)\end{array}$ & $\begin{array}{c}50 \\
(12.95)\end{array}$ & $\begin{array}{c}20 \\
(5.18 \\
\end{array}$ \\
\hline $\begin{array}{l}\text { The Ban } \\
\text { involvec } \\
\text { comn }\end{array}$ & $\begin{array}{c}72 \\
(18.65)\end{array}$ & $\begin{array}{c}131 \\
(33.94)\end{array}$ & $\begin{array}{c}106 \\
(27.46)\end{array}$ & $\begin{array}{c}48 \\
(12.44)\end{array}$ & $\begin{array}{c}29 \\
(7.51\end{array}$ \\
\hline $\begin{array}{l}\text { The Ban } \\
\text { to develo }\end{array}$ & $\begin{array}{c}96 \\
(24.87)\end{array}$ & $\begin{array}{c}142 \\
(36.79)\end{array}$ & $\begin{array}{c}87 \\
(22.54)\end{array}$ & $\begin{array}{c}38 \\
(9.84)\end{array}$ & $\begin{array}{c}23 \\
(5.96\end{array}$ \\
\hline & $(36.01)$ & $(41.45)$ & $\begin{array}{c}63 \\
(16.32)\end{array}$ & $\begin{array}{c}18 \\
(4.66)\end{array}$ & $\begin{array}{r}6 \\
(1.56\end{array}$ \\
\hline
\end{tabular}

\begin{tabular}{|c|c|c|c|c|c|}
\hline to Minority stuc & $\begin{array}{c}121 \\
(31.35)\end{array}$ & $\begin{array}{c}186 \\
(48.19)\end{array}$ & $\begin{array}{c}53 \\
(13.73)\end{array}$ & $\begin{array}{c}15 \\
(3.89)\end{array}$ & $\begin{array}{c}11 \\
(2.85)\end{array}$ \\
\hline & & & & & $\begin{array}{c}2 \\
(0.52 \\
\end{array}$ \\
\hline & $\begin{array}{c}117 \\
(30.31)\end{array}$ & $\begin{array}{c}194 \\
(50.26)\end{array}$ & $\begin{array}{c}53 \\
(13.73)\end{array}$ & & $\begin{array}{c}8 \\
(2.07\end{array}$ \\
\hline & $\begin{array}{c}124 \\
(32.12) \\
\end{array}$ & $\begin{array}{c}183 \\
(47.41) \\
\end{array}$ & $\begin{array}{c}50 \\
(12.95)\end{array}$ & $\begin{array}{c}16 \\
(4.15)\end{array}$ & $\begin{array}{c}13 \\
(3.37)\end{array}$ \\
\hline $\begin{array}{l}\text { Edu } \\
\text { Dev }\end{array}$ & $\begin{array}{c}110 \\
(28.50)\end{array}$ & $\begin{array}{c}192 \\
(49.74)\end{array}$ & $\begin{array}{c}58 \\
(15.03)\end{array}$ & $\begin{array}{c}20 \\
(5.18)\end{array}$ & $\begin{array}{c}6 \\
(1.55\end{array}$ \\
\hline $\begin{array}{r}\text { Condu } \\
\text { don } \\
\mathrm{fr}\end{array}$ & $\begin{array}{c}124 \\
(32.12)\end{array}$ & $\begin{array}{c}165 \\
(42.75)\end{array}$ & $\begin{array}{c}51 \\
(13.21)\end{array}$ & $\begin{array}{c}32 \\
(8.29)\end{array}$ & $\begin{array}{c}14 \\
(3.63\end{array}$ \\
\hline & $(32$. & $\begin{array}{c}189 \\
(48.96) \\
\end{array}$ & $\begin{array}{c}50 \\
(12.95) \\
\end{array}$ & $\begin{array}{c}16 \\
(4.15) \\
\end{array}$ & $\begin{array}{c}6 \\
(1.55 \\
\end{array}$ \\
\hline & $(31.09)$ & $\begin{array}{c}187 \\
(48.44)\end{array}$ & $\begin{array}{c}58 \\
(15.03)\end{array}$ & $\begin{array}{c}11 \\
(2.85)\end{array}$ & $\begin{array}{c}10 \\
(2.59\end{array}$ \\
\hline & (33.67) & $\begin{array}{c}166 \\
(43.01) \\
\end{array}$ & $\begin{array}{c}56 \\
(14.51) \\
\end{array}$ & $\begin{array}{c}25 \\
(6.48) \\
\end{array}$ & $\begin{array}{r}9 \\
(2.3 \\
\end{array}$ \\
\hline d & $\begin{array}{c}128 \\
(33.16)\end{array}$ & $\begin{array}{c}165 \\
(42.75)\end{array}$ & $\begin{array}{c}63 \\
(16.32\end{array}$ & $\begin{array}{c}21 \\
(5.44)\end{array}$ & $\begin{array}{r}9 \\
(2.33\end{array}$ \\
\hline lal & $\begin{array}{c}105 \\
(27.20)\end{array}$ & $\begin{array}{c}186 \\
(48.19)\end{array}$ & $\begin{array}{c}55 \\
(14.25\end{array}$ & $\begin{array}{c}21 \\
(5.44)\end{array}$ & $\begin{array}{c}19 \\
(4.92\end{array}$ \\
\hline & $\begin{array}{c}81 \\
(20.98)\end{array}$ & $\begin{array}{c}208 \\
(53.89)\end{array}$ & $\begin{array}{c}74 \\
(19.17)\end{array}$ & $\begin{array}{c}10 \\
(2.59)\end{array}$ & $\begin{array}{c}13 \\
(3.37\end{array}$ \\
\hline $\begin{array}{l}\text { Improve co } \\
\text { relation }\end{array}$ & $(26.16)$ & $\begin{array}{c}184 \\
(47.67) \\
\end{array}$ & $(16.84)$ & $\begin{array}{c}25 \\
(6.48)\end{array}$ & $\begin{array}{c}11 \\
(2.85)\end{array}$ \\
\hline Improve customer & $\begin{array}{c}118 \\
(30.57)\end{array}$ & $\begin{array}{c}184 \\
(47.67) \\
\end{array}$ & $\begin{array}{c}60 \\
(15.54)\end{array}$ & $\begin{array}{c}16 \\
(4.15)\end{array}$ & $\begin{array}{c}8 \\
(2.07)\end{array}$ \\
\hline & 141 & $\begin{array}{c}196 \\
(50.78)\end{array}$ & $\begin{array}{c}29 \\
(7.51)\end{array}$ & $\begin{array}{c}14 \\
(3.63)\end{array}$ & $\begin{array}{c}6 \\
(1.55\end{array}$ \\
\hline
\end{tabular}

Source: Primary Data

Note: SA - Strongly Agree; A - Agree; N - Neutral; DA Disagree; SDA - Strongly Disagree

The Table. 3 discloses that majority of the customers agree with all the statements regarding the expectation of customers towards the CSR activities of banks, since, the percentage is high for "Agree" and "Strongly Agree" scales when compared to "Disagree" and "Strongly Disagree" scales.

In order to test the reliability of scale, Cronbach's Alpha Test is applied and the results are shown in Table.4.

Table.4. Cronbach's Alpha Test for Expectation of Customers towards the CSR Activities of Banks.

\begin{tabular}{|c|c|}
\hline Cronbach's Alpha & No of items \\
\hline .920 & 43 \\
\hline
\end{tabular}

Source: Computed Data

From Table.4 it is clear that, the Cronbach's Alpha value of .920 indicates that the scale is considered highly reliable. 


\subsection{IDENTIFICATION OF LEVEL OF EXPECTATION OF CUSTOMERS TOWARDS CSR ACTIVITIES OF BANKS}

The scores are aligned in the order of five for 'Strongly Agree', four for 'Agree', three for 'Neutral', two for 'Disagree' and one for 'Strongly Disagree'. The score value for every sample customers is obtained. The level of expectation has been classified into three categories, namely low level, medium level and high level of analytical purpose. While the score value of the respondent $\geq(\bar{X}-\mathrm{SD})$ and the score value of respondent $\leq(\bar{X}-$ $\mathrm{SD})$ have been classified as high level expectation and low level expectation respectively and score values between $(\bar{X}-\mathrm{SD})$ and ( $\bar{X}-\mathrm{SD}$ ) have been clarified as medium level expectation, $\bar{X}$ and SD are the arithmetic mean and standard deviation, which are calculated from the score values of 386 respondents. The arithmetic mean and standard deviation are 86.58 and 19.11 respectively.

$(\bar{X}-\mathrm{SD})=86.58+19.11=105.69$ and above - High level

$(\bar{X}-\mathrm{SD})=86.58-19.11=67.47$ and below - Low level

$(\bar{X}-\mathrm{SD})$ to $(\bar{X}+\mathrm{SD})=67.47$ to $105.69-$ Medium level

The Table. 5 reveals the level of expectation of 386 sample customers.

Table.5. Level of Expectation of the Customers towards the CSR Activities of Banks

\begin{tabular}{|c|c|c|}
\hline S. No & Level of Expectation & $\begin{array}{c}\text { No of Customers } \\
\text { (Percent to Total) }\end{array}$ \\
\hline 1. & High & $57(14.77)$ \\
\hline 2. & Medium & $273(70.73)$ \\
\hline 3. & Low & $56(14.50)$ \\
\hline & Total & $386(100.00)$ \\
\hline
\end{tabular}

Source: Computed Data

From Table.5 it is clear that out of 386 customers, 57 customers $(14.77 \%)$ under the category of high level expectation, 273 customers $(70.73 \%)$ come under the category of medium level expectation and the remaining 56 customers (14.50\%) fall under the category of low level expectation.

\subsection{SOCIO - ECONOMIC VARIABLES AND LEVEL OF EXPECTATION TOWARDS CSR ACTIVITIES OF BANKS: APPLICATION OF CHI - SQUARE TEST}

In order to test the relationship between socio-economic variables, namely, gender, age, place of residence, literacy, educational status, employment, occupation, monthly income, type of account, period of transaction and category of having account and level of expectation towards the CSR activities of banks, the researcher has applied Chi- Square Test and framed the hypotheses that "there is no relationship between age, gender, place of residence, literacy, educational status, employment, occupation, monthly income, type of account, period of transaction and category of having account of the customers and their level of expectation towards the CSR activities of banks". The result is presented in the Table. 6 and Table. 7.
Table.6. Socio Economic Variables and Level of Expectation towards CSR Activities of Banks

\begin{tabular}{|c|c|c|c|c|}
\hline \multirow{2}{*}{$\begin{array}{c}\text { Socio } \\
\text { Economic } \\
\text { Variables }\end{array}$} & \multicolumn{3}{|c|}{ Level of Expectation } & \multirow{2}{*}{ Total } \\
\hline & High & Medium & Low & \\
\hline \multicolumn{5}{|c|}{ Gender } \\
\hline Male & $\begin{array}{c}44 \\
(11.40 \%)\end{array}$ & $\begin{array}{c}159 \\
(37.30 \%)\end{array}$ & $\begin{array}{c}38 \\
(9.84 \%) \\
\end{array}$ & $\begin{array}{c}241 \\
(62.44 \%)\end{array}$ \\
\hline Female & $\begin{array}{c}13 \\
(3.37 \%)\end{array}$ & $\begin{array}{c}114 \\
(29.53 \%)\end{array}$ & $\begin{array}{c}18 \\
(4.66 \%)\end{array}$ & $\begin{array}{c}145 \\
(37.56 \%)\end{array}$ \\
\hline Total & $\begin{array}{c}57 \\
(14.77 \%)\end{array}$ & $\begin{array}{c}273 \\
(70.73 \%)\end{array}$ & $\begin{array}{c}56 \\
(14.50 \%)\end{array}$ & $\begin{array}{c}386 \\
(100.00 \%)\end{array}$ \\
\hline \multicolumn{5}{|c|}{ Age } \\
\hline Below 30 & $\begin{array}{c}34 \\
(8.81 \%)\end{array}$ & $\begin{array}{c}166 \\
(43.01 \%)\end{array}$ & $\begin{array}{c}50 \\
(12.95 \%) \\
\end{array}$ & $\begin{array}{c}250 \\
(64.77 \%) \\
\end{array}$ \\
\hline 31 to 40 & $\begin{array}{c}12 \\
(3.11 \%)\end{array}$ & $\begin{array}{c}51 \\
(13.21 \%)\end{array}$ & $\begin{array}{c}6 \\
(1.55 \%)\end{array}$ & $\begin{array}{c}69 \\
(17.87 \%)\end{array}$ \\
\hline 41 to 50 & $\begin{array}{c}7 \\
(1.81 \%) \\
\end{array}$ & $\begin{array}{c}39 \\
(10.11 \%)\end{array}$ & - & $\begin{array}{c}46 \\
(11.92 \% \\
\end{array}$ \\
\hline Above 50 & $\begin{array}{c}4 \\
(1.04 \%) \\
\end{array}$ & $\begin{array}{c}17 \\
(4.40 \%) \\
\end{array}$ & - & $\begin{array}{c}21 \\
(5.44 \%) \\
\end{array}$ \\
\hline Total & $\begin{array}{c}57 \\
(14.77 \%) \\
\end{array}$ & $\begin{array}{c}273 \\
(70.73 \%) \\
\end{array}$ & $\begin{array}{c}56 \\
(14.50 \%) \\
\end{array}$ & $\begin{array}{c}386 \\
(100.00 \%) \\
\end{array}$ \\
\hline \multicolumn{5}{|c|}{ Place of Residence } \\
\hline Rural & $\begin{array}{c}23 \\
(5.96 \%) \\
\end{array}$ & $\begin{array}{c}148 \\
(38.34 \%)\end{array}$ & $\begin{array}{c}38 \\
(9.84 \%) \\
\end{array}$ & $\begin{array}{c}209 \\
(54.15 \%)\end{array}$ \\
\hline Urban & $\begin{array}{c}34 \\
(8.81 \%)\end{array}$ & $\begin{array}{c}125 \\
(32.39 \%)\end{array}$ & $\begin{array}{c}18 \\
(4.66 \%)\end{array}$ & $\begin{array}{c}177 \\
(45.85 \%)\end{array}$ \\
\hline Total & $\begin{array}{c}57 \\
(14.77 \%) \\
\end{array}$ & $\begin{array}{c}273 \\
(70.73 \%)\end{array}$ & $\begin{array}{c}56 \\
(14.50 \%) \\
\end{array}$ & $\begin{array}{c}386 \\
(100.00 \%)\end{array}$ \\
\hline \multicolumn{5}{|c|}{ Literacy of the Respondents } \\
\hline Literate & $\begin{array}{c}55 \\
(14.25 \%)\end{array}$ & $\begin{array}{c}243 \\
(62.92 \%)\end{array}$ & $\begin{array}{c}54 \\
(13.98 \%)\end{array}$ & $\begin{array}{c}352 \\
(91.19 \%)\end{array}$ \\
\hline Illiterate & $\begin{array}{c}2 \\
(0.52 \%\end{array}$ & $\begin{array}{c}30 \\
(7.77 \%)\end{array}$ & $\begin{array}{c}2 \\
(0.52 \%)\end{array}$ & $\begin{array}{c}34 \\
(8.81 \%)\end{array}$ \\
\hline Total & $\begin{array}{c}57 \\
(14.77 \%) \\
\end{array}$ & $\begin{array}{c}273 \\
(70.73 \%) \\
\end{array}$ & $\begin{array}{c}56 \\
(14.50 \%) \\
\end{array}$ & $\begin{array}{c}386 \\
(100.00 \%)\end{array}$ \\
\hline \multicolumn{5}{|c|}{ Educational Status } \\
\hline S.S.L.C & $\begin{array}{c}12 \\
(3.41 \%)\end{array}$ & $\begin{array}{c}31 \\
(8.80 \%)\end{array}$ & $\begin{array}{c}2 \\
(0.57 \%)\end{array}$ & $\begin{array}{c}45 \\
(12.78 \%)\end{array}$ \\
\hline $\begin{array}{c}\text { Higher } \\
\text { Secondary }\end{array}$ & $\begin{array}{c}7 \\
(1.99 \%) \\
\end{array}$ & $\begin{array}{c}23 \\
(6.53 \%) \\
\end{array}$ & $\begin{array}{c}6 \\
(1.71 \%) \\
\end{array}$ & $\begin{array}{c}36 \\
(10.23 \%) \\
\end{array}$ \\
\hline Diploma & $\begin{array}{c}4 \\
(1.14 \%)\end{array}$ & $\begin{array}{c}26 \\
(7.39 \%)\end{array}$ & $\begin{array}{c}10 \\
(2.83 \%)\end{array}$ & $\begin{array}{c}40 \\
(11.36 \%)\end{array}$ \\
\hline $\begin{array}{c}\text { Under } \\
\text { Graduate }\end{array}$ & $\begin{array}{c}19 \\
(5.40 \%)\end{array}$ & $\begin{array}{c}84 \\
(23.86 \%)\end{array}$ & $\begin{array}{c}14 \\
(3.98 \%)\end{array}$ & $\begin{array}{c}117 \\
(33.24 \%)\end{array}$ \\
\hline $\begin{array}{c}\text { Post } \\
\text { Graduate }\end{array}$ & $\begin{array}{c}13 \\
(3.69 \%)\end{array}$ & $\begin{array}{c}81 \\
(23.02 \%)\end{array}$ & $\begin{array}{c}20 \\
(5.68 \%)\end{array}$ & $\begin{array}{c}114 \\
(32.39 \%)\end{array}$ \\
\hline Total & $\begin{array}{c}55 \\
(15.63 \%)\end{array}$ & $\begin{array}{c}245 \\
(69.60 \%)\end{array}$ & $\begin{array}{c}52 \\
(14.77 \%)\end{array}$ & $\begin{array}{c}352 \\
(100.00 \%)\end{array}$ \\
\hline \multicolumn{5}{|c|}{ Occupation } \\
\hline Business & 6 & 28 & 6 & 40 \\
\hline
\end{tabular}




\begin{tabular}{|c|c|c|c|c|}
\hline Man & $(1.55 \%)$ & $(7.26 \%$ & $(1.55 \%)$ & $(10.36 \%)$ \\
\hline $\begin{array}{c}\text { Government } \\
\text { Employees }\end{array}$ & $\begin{array}{c}7 \\
(1.81 \%)\end{array}$ & $\begin{array}{c}20 \\
(5.18 \%)\end{array}$ & $\begin{array}{c}2 \\
(0.52 \%)\end{array}$ & $\begin{array}{c}29 \\
(7.51 \%)\end{array}$ \\
\hline $\begin{array}{c}\text { Private } \\
\text { Employees }\end{array}$ & $\begin{array}{c}27 \\
(7.00 \%)\end{array}$ & $\begin{array}{c}97 \\
(25.13 \%)\end{array}$ & $\begin{array}{c}16 \\
(4.14 \%)\end{array}$ & $\begin{array}{c}140 \\
(36.27 \%)\end{array}$ \\
\hline Professionals & $\begin{array}{c}0 \\
(0.00 \%) \\
\end{array}$ & $\begin{array}{c}2 \\
(0.52 \%) \\
\end{array}$ & $\begin{array}{c}2 \\
(0.52 \%) \\
\end{array}$ & $\begin{array}{c}4 \\
(1.04 \%) \\
\end{array}$ \\
\hline Agriculturist & $\begin{array}{c}1 \\
(0.26 \%)\end{array}$ & $\begin{array}{c}15 \\
(3.88 \%)\end{array}$ & $\begin{array}{c}0 \\
(0.00 \%)\end{array}$ & $\begin{array}{c}16 \\
(4.14 \%)\end{array}$ \\
\hline Coolie & $\begin{array}{c}1 \\
(0.26 \%)\end{array}$ & $\begin{array}{c}7 \\
(1.81 \%)\end{array}$ & $\begin{array}{c}8 \\
(2.07 \%)\end{array}$ & $\begin{array}{c}16 \\
(4.14 \%)\end{array}$ \\
\hline Student & $\begin{array}{c}8 \\
(2.08 \%) \\
\end{array}$ & $\begin{array}{c}64 \\
(16.58 \%) \\
\end{array}$ & $\begin{array}{c}18 \\
(4.66 \%) \\
\end{array}$ & $\begin{array}{c}90 \\
(23.32 \%) \\
\end{array}$ \\
\hline Housewives & $\begin{array}{c}6 \\
(1.55 \%) \\
\end{array}$ & $\begin{array}{c}30 \\
(7.78 \%) \\
\end{array}$ & $\begin{array}{c}0 \\
(0.00 \%) \\
\end{array}$ & $\begin{array}{c}36 \\
(9.33 \%) \\
\end{array}$ \\
\hline Job Seekers & $\begin{array}{c}1 \\
(0.26 \%) \\
\end{array}$ & $\begin{array}{c}10 \\
(2.59 \%) \\
\end{array}$ & $\begin{array}{c}4 \\
(1.04 \%) \\
\end{array}$ & $\begin{array}{c}15 \\
(3.89 \%) \\
\end{array}$ \\
\hline Total & $\begin{array}{c}57 \\
(14.77 \%)\end{array}$ & $\begin{array}{c}273 \\
(70.73 \%)\end{array}$ & $\begin{array}{c}56 \\
(14.50 \%)\end{array}$ & $\begin{array}{c}386 \\
(100.00 \%)\end{array}$ \\
\hline \multicolumn{5}{|c|}{ Monthly Income } \\
\hline $\begin{array}{c}\text { Upto } \\
\text { Rs.10000 } \\
\end{array}$ & $\begin{array}{c}21 \\
(8.57 \%) \\
\end{array}$ & $\begin{array}{c}86 \\
(35.11 \%) \\
\end{array}$ & $\begin{array}{c}14 \\
(5.71 \%) \\
\end{array}$ & $\begin{array}{c}121 \\
(49.39 \%) \\
\end{array}$ \\
\hline $\begin{array}{c}\text { Rs. } 10001 \text { to } \\
\text { Rs. } 20000\end{array}$ & $\begin{array}{c}12 \\
(4.90 \%) \\
\end{array}$ & $\begin{array}{c}53 \\
(21.63 \%) \\
\end{array}$ & $\begin{array}{c}11 \\
(4.49 \%) \\
\end{array}$ & $\begin{array}{c}76 \\
(31.02 \%) \\
\end{array}$ \\
\hline $\begin{array}{c}\text { Rs.20001 to } \\
\text { Rs.30000 }\end{array}$ & $\begin{array}{c}4 \\
(1.63 \%) \\
\end{array}$ & $\begin{array}{c}28 \\
(11.43 \%) \\
\end{array}$ & $\begin{array}{c}2 \\
(0.82 \%) \\
\end{array}$ & $\begin{array}{c}34 \\
(13.88 \%) \\
\end{array}$ \\
\hline $\begin{array}{c}\text { Above } \\
\text { Rs.30000 }\end{array}$ & $\begin{array}{c}3 \\
(1.22 \%) \\
\end{array}$ & $\begin{array}{c}9 \\
(3.67 \%) \\
\end{array}$ & $\begin{array}{c}2 \\
(0.82 \%) \\
\end{array}$ & $\begin{array}{c}14 \\
(5.71 \%) \\
\end{array}$ \\
\hline Total & $\begin{array}{c}40 \\
(16.32 \%)\end{array}$ & $\begin{array}{c}176 \\
(71.84 \%)\end{array}$ & $\begin{array}{c}29 \\
(11.84 \%)\end{array}$ & $\begin{array}{c}245 \\
(100.00 \%)\end{array}$ \\
\hline
\end{tabular}

\begin{tabular}{|c|c|c|c|c|}
\hline \multicolumn{5}{|c|}{ Type of Account } \\
\hline $\begin{array}{c}\text { Saving } \\
\text { Account }\end{array}$ & $\begin{array}{c}54 \\
(14.00 \%)\end{array}$ & $\begin{array}{c}261 \\
(67.62 \%)\end{array}$ & $\begin{array}{c}55 \\
(14.24 \%)\end{array}$ & $\begin{array}{c}370 \\
(95.86 \%)\end{array}$ \\
\hline $\begin{array}{c}\text { Current } \\
\text { Account }\end{array}$ & 3 & 10 & 1 & 14 \\
\hline NRI & $0.77 \%)$ & $(2.69 \%)$ & $(0.26 \%)$ & $(3.36 \%)$ \\
Account & $(0.00 \%)$ & 2 & 0 & 2 \\
\hline Total & 57 & 273 & 56 & $(0.00 \%)$ \\
& $(14.77 \%)$ & $(70.73 \%)$ & $(14.50 \%)$ & $(100.00 \%)$ \\
\hline
\end{tabular}

\begin{tabular}{|c|c|c|c|c|}
\hline \multicolumn{4}{c}{ Period of Transaction } \\
\hline $\begin{array}{c}\text { Below } 5 \\
\text { Years }\end{array}$ & $\begin{array}{c}46 \\
(11.92 \%)\end{array}$ & $\begin{array}{c}173 \\
(44.82 \%)\end{array}$ & $\begin{array}{c}36 \\
(9.32 \%)\end{array}$ & $\begin{array}{c}255 \\
(66.06 \%)\end{array}$ \\
\hline $\begin{array}{c}5 \text { to } 10 \\
\text { Years }\end{array}$ & $\begin{array}{c}10 \\
(2.59 \%)\end{array}$ & $\begin{array}{c}74 \\
(19.17 \%)\end{array}$ & $\begin{array}{c}18 \\
(4.66 \%)\end{array}$ & $\begin{array}{c}102 \\
(26.43 \%)\end{array}$ \\
\hline $\begin{array}{c}11 \text { to } 15 \\
\text { Years }\end{array}$ & 1 & 24 & 2 & 27 \\
$(0.26 \%)$ & $(6.22 \%)$ & $(0.52 \%)$ & $(6.99 \%)$ \\
\hline $\begin{array}{c}\text { Above } 15 \\
\text { Years }\end{array}$ & 0 & 2 & 0 & 2 \\
$(0.00 \%)$ & $(0.52 \%)$ & $(0.00 \%)$ & $(0.52 \%)$ \\
\hline Total & $\begin{array}{c}57 \\
(14.77 \%)\end{array}$ & $\begin{array}{c}273 \\
(70.73 \%)\end{array}$ & $\begin{array}{c}56 \\
(14.50 \%)\end{array}$ & $\begin{array}{c}386 \\
(100.00 \%)\end{array}$ \\
\hline \multicolumn{7}{r}{ Category } & &
\end{tabular}

Category of Bank

\begin{tabular}{|c|c|c|c|c|}
\hline $\begin{array}{c}\text { Public } \\
\text { sector bank }\end{array}$ & $\begin{array}{c}40 \\
(10.36 \%)\end{array}$ & $\begin{array}{c}181 \\
(46.90 \%)\end{array}$ & $\begin{array}{c}38 \\
(9.84 \%)\end{array}$ & $\begin{array}{c}259 \\
(67.10 \%)\end{array}$ \\
\hline $\begin{array}{c}\text { Private } \\
\text { sector bank }\end{array}$ & $\begin{array}{c}15 \\
(3.89 \%)\end{array}$ & $\begin{array}{c}73 \\
(18.91 \%)\end{array}$ & $\begin{array}{c}16 \\
(4.14 \%)\end{array}$ & $\begin{array}{c}104 \\
(26.94 \%)\end{array}$ \\
\hline $\begin{array}{c}\text { Regional } \\
\text { rural bank }\end{array}$ & $\begin{array}{c}0 \\
(0.00 \%)\end{array}$ & $\begin{array}{c}13 \\
(3.37 \%)\end{array}$ & $\begin{array}{c}0 \\
(0.00 \%)\end{array}$ & $\begin{array}{c}13 \\
(3.37 \%)\end{array}$ \\
\hline $\begin{array}{c}\text { Co- } \\
\text { operative } \\
\text { bank }\end{array}$ & $\begin{array}{c}2 \\
(0.52 \%)\end{array}$ & $\begin{array}{c}6 \\
(1.55 \%)\end{array}$ & $\begin{array}{c}2 \\
(0.52 \%)\end{array}$ & $\begin{array}{c}10 \\
(2.59 \%)\end{array}$ \\
\hline Total & $\begin{array}{c}57 \\
(14.77 \%)\end{array}$ & $\begin{array}{c}273 \\
(70.73 \%)\end{array}$ & $\begin{array}{c}56 \\
(14.50 \%)\end{array}$ & $\begin{array}{c}386 \\
(100.00 \%)\end{array}$ \\
\hline
\end{tabular}

Source: Primary Data

The Table.6 represents that 159 male customers, 166 customers are below 30 years of age group, 148 rural customers, 243 literates, 84 under graduates, 97 private employees, 86 customers earn monthly income of Rs.10000, 261 customers having savings account, 173 customers have below five years of account and 181 customers have account in public sector bank with medium level of expectation towards CSR activities of banks. The Chi-Square test result is presented in the Table.7.

Table.7. Chi-Square Results of Socio Economic Variables and Level of Expectation towards CSR Activities of Banks

\begin{tabular}{|c|c|c|}
\hline Socio Economic Variables & $\begin{array}{c}\text { Calculated } \\
\text { Value }\end{array}$ & P Value \\
\hline Gender & 8.042 & 0.018 \\
\hline Age & 19.700 & 0.003 \\
\hline Place of Residence & 8.610 & 0.014 \\
\hline Literacy of the Customers & 5.521 & 0.063 \\
\hline Educational Status & 23.065 & 0.027 \\
\hline Occupation & 32.463 & 0.001 \\
\hline Monthly Income & 32.121 & 0.000 \\
\hline Type of Account & 16.074 & 0.013 \\
\hline Period of Transaction & 9.881 & 0.130 \\
\hline Category of Bank & 9.609 & 0.294 \\
\hline
\end{tabular}

From the above table, we can study the relationship between the socio economic variables and level of expectation of CSR activities of banks with the help of Chi-Square Test. The ChiSquare Test result reveals that there is no relationship between literacy level, period of transaction and category of bank and their level of expectations towards the CSR activities of banks. Because, the $\mathrm{P}$ value is greater than the significant value at $5 \%$ level. Other socio economic variables are less than the significant value at $5 \%$ level. So, the there is a relationship between gender, age, place of residence, educational status, occupation, monthly income and type of account and their level of expectations towards the CSR activities of banks.

\section{FINDINGS}

To test the relationship between the socio-economic variables and their level of expectation of Corporate Social Responsibilities of banks, Chi-square test has been applied. The analysis reveals that most of the customers in Virudhunagar District have medium 
level of expectations towards Corporate Social Responsibility of banks. The Chi-square test reveals that there is no relationship between literacy level, period of transaction and category of bank and their level of expectations towards the CSR activities of banks. This study also reveals that there is a relationship between gender, age, place of residence, educational status, occupation, monthly income and type of account and their level of expectations towards the CSR activities of banks.

\section{SUGGESTIONS}

The following are the suggestions of the study.

- This study also reveals that there is a relationship between gender, age, place of residence, educational status, occupation, monthly income and type of account and their level of expectation towards the CSR activities of banks. Expectations of customer differ on the basis of socio economic profile and banking profile. Banks may consider or give extra benefits on the basis of potential customer profile.

- Provide special loans to differently disabled citizens, Give high interest against investment, Involve reduction of air pollutant, Charge minimum interest against loans are identified the high loading factors on the basis of the opinion of the customers about future expectations of banks towards CSR. In future the banks may take in to account for the above expectations of the customers and implement as early as possible.

\section{CONCLUSION}

CSR has become necessary for organizational health and wealth. It plays a role of supporter and facilitator in the journey that enterprises undertake to reach the peak along with highest ethical standards. It will help banks in their endeavors in serving the cause of society. It will also help the banks in evolving a suitable mechanism for implementing the CSR programmes and keep a close watch on their effects. Government was the principal shareholder and promoter of corporate social responsibility practices of every country in the world. The Various form of business organization was under took second part of CSR. Good CSR practices are essential for sustainable business. It generates long-term value to the stakeholders and the society in particular in full.

\section{REFERENCES}

[1] Nidhi Malik, "Corporate Social Responsibility in Indian Banking Industry: Study on Attempts of HDFC Bank", International Journal of Research-Granthaalayah, Vol. 4, No. 8, pp. 62-74, 2016.

[2] M. Abe and N. Freeman, "The 3Cs for Responsible Banking in Asia and the Pacific: Corporate Governance, Corporate Social Responsibility and Corporate Sustainability", Technical Report, United Nations ESCAP, pp. 1-52, 2014.

[3] A. Ali, Ellisha Nasruddin and Soh Keng Lin, "The Relationship between Internal Corporate Social Responsibility and Organizational Commitment within the
Banking Sector in Jordan", International Scholarly and Scientific Research and Innovation, Vol. 4, No. 7, pp. 1842 1861, 2010.

[4] Sanjeev K. Sharma, "Comparative Study of Corporate Social Responsibility in Selected Public and Private Sector Banks", International Journal of Multidisciplinary Research, Vol. 1, No. 3, pp. 10-17, 2016.

[5] Prerak Kafle and Deepika Tiwari, "The Assessment of a Nepalese Bank in terms of Corporate Social Responsibility", International Journal of Pharmaceutical Sciences and Business Management, Vol. 2, No. 1, pp. 28-34, 2014.

[6] P. Vijay and N. Divya, "Impact of Corporate Social Responsibility initiatives of Indian Banking Sector", International Research Journal of Business and Management, Vol. 7, No. 12, pp. 29-38, 2014.

[7] V. Carolin Juliy Pushpam, R. Karthi and B. Asha Daisy, "Corporate Social Responsibility of Banks in India", International Journal of Scientific and Research Publication, Vol. 5, No. 4, pp. 1-4, 2015.

[8] Shravya Saxena, "A Comparative Study of Corporate Social Responsibility (CSR) of Private and Public Sector Banks", World Wide Journal of Multidisciplinary Research and Development, Vol. 2, No. 1, pp. 21-23, 2016.

[9] Jamaliah Mohd Yusof, Hasman Abdul Manan, Norzitah Abd Karim and Nor Akila Mohd Kassim, "Customer's Loyalty effects of CSR Initiatives", Procedia-Social and Behavioral Sciences, Vol. 170, pp. 109-119, 2015.

[10] Debanga Mukherjee, "Corporate Social Responsibility: A Study on Initiatives Taken By Selected Indian Companies", Global Journal of Commerce and Management Perspective, Vol. 4, No. 5, pp. 1-3, 2015.

[11] Eliza Sharma and Mukta Mani, "Corporate Social Responsibility: An Analysis of Indian Commercial Banks”, AIMA Journal of Management and Research, Vol. 7, No. 1, pp. 1-16, 2013.

[12] G. Sankaravadivoo, "Corporate Social Responsibility: An Analysis on Selected Banks in India", Renewable Research Journal, Vol. 3, No. 3, pp. 23-33, 2016.

[13] Sandeep Kaur, "A Study on Corporate Social Responsibility (CSR) in Indian Banking Sector", International Journal of Current Research, Vol. 8, No. 11, pp. 42604-42606, 2016.

[14] Pooja Rani and M.S. Khan, "Customer Perception towards Corporate Social Responsibility (CSR) in Banking Sector”, International Journal of Applied Research, Vol. 1, No. 11, pp. 265-268, 2015.

[15] N. Senthikumar, A. Ananth and A. Arulraj, "Impact of Corporate Social Responsibility on Customer Satisfaction in Banking Service", African Journal of Business Management, Vol. 5, No. 7, pp. 3028-3039, 2011.

[16] Nevine Sobhy Abdel Megeid, "The Impact of Service Quality on Financial Performance and Corporate Social Responsibility: Conventional Versus Islamic Banks in Egypt", International Journal of Finance and Accounting, Vol. 2, No. 3, pp. 150-163, 2013.

[17] Ramdeep Mann and Karamjeet Singh, "Corporate Social Responsibility and Financial Performance: A Study of Indian Banking Sector", Available at: http://pjitm.com/Doc/issu\%20Jan\%20\%20June\%202016/PAPER\%20-\%204.pdf. 
[18] Rajnish Yadav and F.B. Singh, "Impact of Corporate Social Responsibility on Financial Performance of Indian Commercial Banks-An Analysis", Imperial Journal of Interdisciplinary Research, Vol. 2, No. 12, pp. 1113-1122, 2016.

[19] Mahjabeen Ferdous and Md. Moniruzzaman, “An Empirical Evidence of Corporate Social Responsibility by Banking Sector based on Bangladesh", Asian Business Review, Vol. 2, No. 5, pp. 82-87, 2013.

[20] Oluwarotimi Kude and Derek Watson, “An Empirical Study on Corporate Social Responsibility in the Banking Sector", SEGi Review, Vol. 5, No. 1, pp. 47-54, 2012.

[21] Yen Thi Hoang, "CSR in Banking Sector-A Literature Review and New Research Directions", International
Journal of Economics, Commerce and Management United Kingdom, Vol. 2, No. 11, pp. 1-22, 2014.

[22] M. Shoukat Malik and Muhammad Nadeem, "Impact of Corporate Social Responsibility on the Financial Performance of Banks in Pakistan", International Letters of Social and Humanistic Sciences, Vol. 21, pp. 9-19, 2014.

[23] Namrata Singh, Rajlaxmi Srivastava and Rajni Rastogi, "Lighting the Lamp of Education: Role of Indian Banking Sector towards the Corporate Social Responsibility in achieving Development Goals", International Journal of Multidisciplinary and Current Research, Vol. 3, pp. 440446, 2015. 